\title{
NATUREVIEW
}

REVIEWS AND COMMENT FROM THE NATURE PUBLISHING GROUP

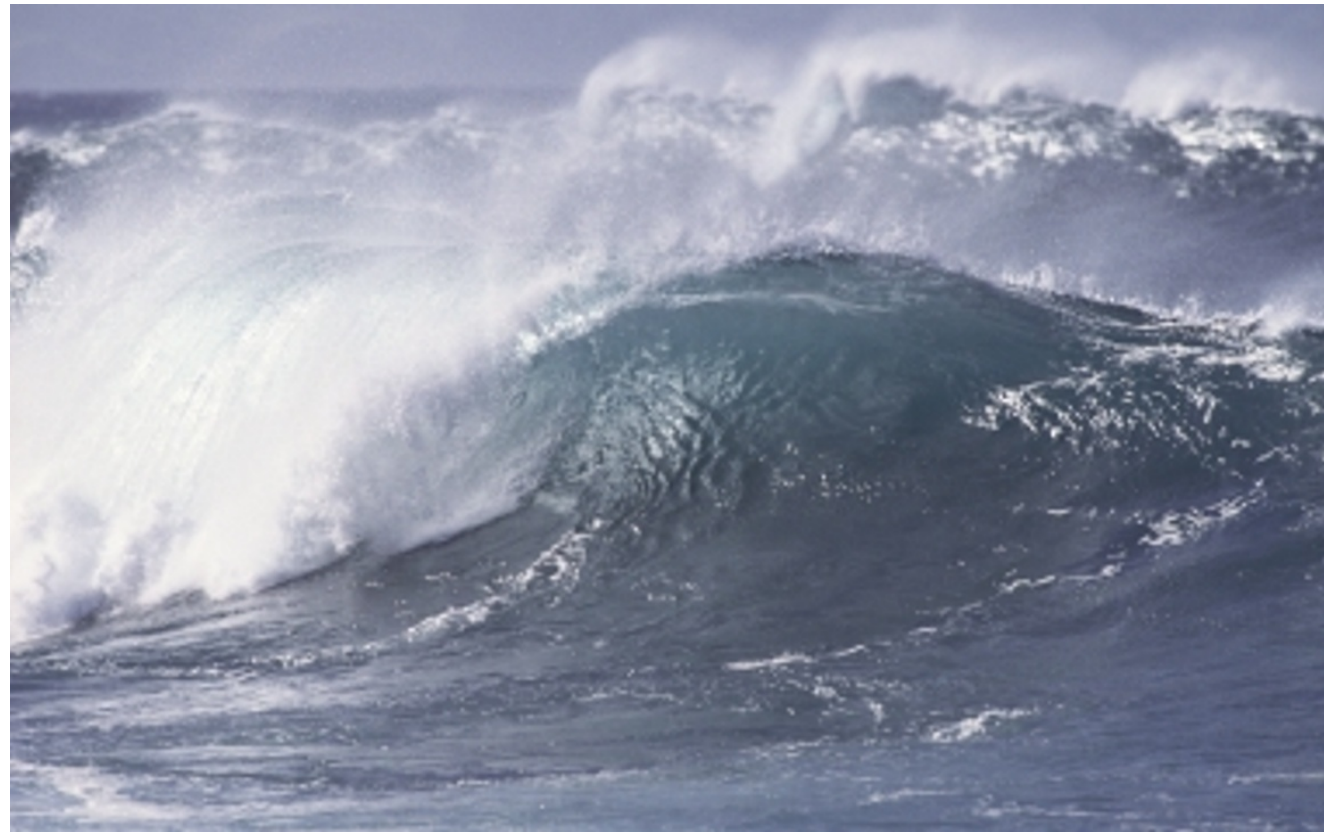

Web focus - Ocean Genomics Nature 28 August 2003. A collection of new - and archived - articles which highlight the significance of marine microbial genome sequences, and microbial contributions to the ocean food web, for understanding marine biodiversity, ecology and biogeochemistry.

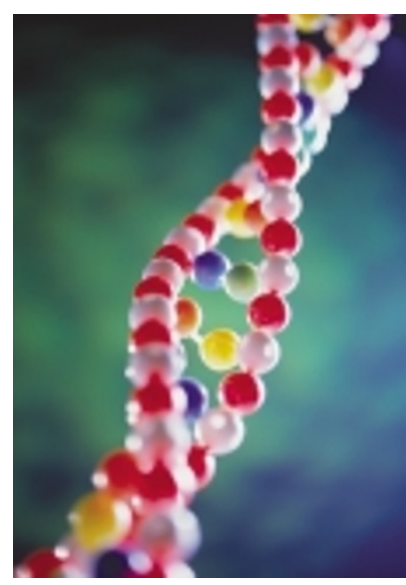

- Anthrax delivers a lethal blow to host immunity

Michael N. Starnbach and

R. John Collier

Nature Medicine August (2003).
4 Initiation of DNA replication: lessons from viral initiator proteins Arne Stenlund

Nature Reviews Molecular Cell Biology October (2003).

Studying viruses has brought many insights into basic cellular processes. In this review, the mechanisms of action of viral initiators provides a model for more complex initiator proteins, such as the origin recognition complex, which is a conserved initiator present in eukaryotes.

- Defensins: antimicrobial peptides of innate immunity Tomas Ganz

Nature Reviews Immunology September (2003).
- Macrophage migration inhibitory factor: a regulator of innate immunity

Thierry Calandra and Thierry Roger Nature Reviews Immunology October (2003).

- Rise of the nanomachines Stephen J Russell

Nature Biotechnology August (2003).

This News \& Views article looks at the generation of nanoparticles that combine features of viral and non-viral vectors. By coupling the entry strategy of a virus with non-viral components, this development could allow the safe targeted delivery of nanoparticles loaded with drugs, genes or proteins to hepatocytes.
- Quest for SARS source gathers pace in bid to thwart resurgence Alison Abbott Nature 28 August 2003

A surprising number of animals have tested positive for the SARS coronavirus. The validity of tests has been questioned, and as winter approaches, scientists are a long way from identifying which species is the true reservoir for the disease.

$\nabla$ Protecting your inventions: the patent system Philip M. Webber Nature Reviews Drug Discovery October 2003

Years of hard work have come to fruition and you have uncovered a potentially lucrative target molecule, drug or process. But knowledge of the patent system is essential to understand how to protect the fruits of your research. This review details what a patent is, how to get one, and the rights that it might confer.

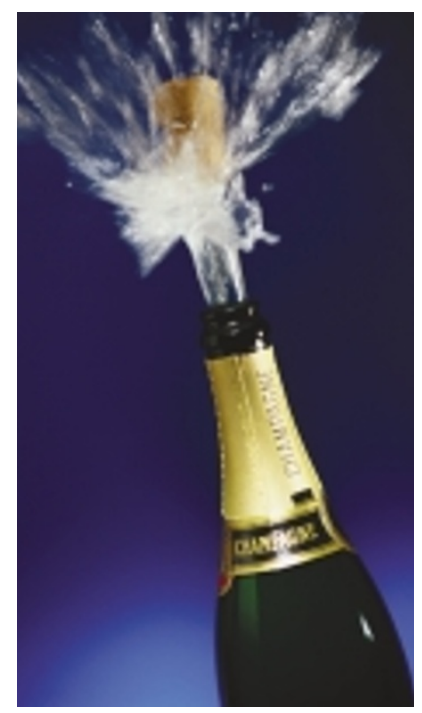




\section{ONLINE ONLY}

Complete list of urls that can be linked to in Natureview section

http://www.nature.com/nature/
http://www.nature.com/nrc/

http://www.nature.com/nrd/

http://www.nature.com/nrg/

http://www.nature.com/nri/

http://www.nature.com/nrmicro/

http://www.nature.com/nrm/

http://www.nature.com/nrn/

http://www.nature.com/nbt/

http://www.nature.com/ncb/

http://www.nature.com/ng/

http://www.nature.com/ni/

http://www.nature.com/nm/

http://www.nature.com/neuro/

http://www.nature.com/nsb/
Nature

Nature Reviews Cancer

Nature Reviews Drug Discovery

Nature Reviews Genetics

Nature Reviews Immunology

Nature Reviews Microbiology

Nature Reviews Molecular Cell Biology

Nature Reviews Neuroscience

Nature Biotechnology

Nature Cell Biology

Nature Genetics

Nature Immunology

Nature Medicine

Nature Neuroscience

Nature Structural Biology 